\title{
Studi Fisikokimia Betasianin Dalam Kulit Buah Naga dan Aplikasinya Sebagai Pewarna Merah Alami Sediaan Farmasi
}

\section{(Physicochemical Study of Betacyanin from Dragon Fruit Rind and Its Application as Natural Dye for Pharmaceutical Dosage Form)}

\author{
Ridho Asra ${ }^{1 *}$, Rina Desni Yetti ${ }^{1}$, Rusdi $^{1}$, Selly Audina ${ }^{1}$, Nessa Nessa $^{2}$ \\ ${ }^{1}$ Sekolah Tinggi Ilmu Farmasi (STIFARM) Padang, Indonesia, 25147 \\ ${ }^{2}$ Sekolah Tinggi Farmasi Indonesia Yayasan Perintis (STIFI) Padang, Indonesia, 25586
}

Article Info:

Received: 19 August 2019

in revised form: 22 September 2019

Accepted: 2 October 2019

Available Online: 9 October 2019

Keywords:

Betacyanin

Dragon Fruit Rind

Natural Dye

Corresponding Author:

Ridho Asra

Sekolah Tinggi Ilmu Farmasi

(STIFARM)

Padang, 25147

Indonesia

email: ridhoasra@gmail.com

\begin{abstract}
The rind of dragon fruit (Hylocereus lemairel (Hook.) Britton \& Rose) is a waste material that has not been optimally utilized. The rind contains betacyanin pigment that has many benefits in pharmaceutical products. The study aimed to characterize the physicochemical properties, to evaluate the stability and to apply betacyanin in dragon fruit rind as a natural dye. The extraction process was done by using water as solvent which was sonicated at $50 \mathrm{kHz}$ for 30 minutes at $25^{\circ} \mathrm{C}$. Extract was freeze dried for 48 hours. The dried extract was purified by using preparative TLC and physicochemically analyzed by using UV-Vis and FTIR spectrophotometer. The stability of betacyanin extract against $\mathrm{pH}$ and temperature was examined and applied as a dye in tablet imprinting. The result of this study indicated that betacyanin was found at $\mathrm{R}_{\mathrm{f}}$ value of 0.6 same as the betacyanin standard. The maximum wavelength of betacyanin was obtained at $534 \mathrm{~nm}$ and the IR spectra showed similarity with betacyanin standard with the same functional groups between $4000-600 \mathrm{~cm}^{-1}$ although there was a slight shift in the wavenumber but it still in the range. The stability study were stable at temperature below $40{ }^{\circ} \mathrm{C}$ and at range $\mathrm{pH}$ 4-6. Betacyanin applications as natural dye of tablet have been successfully carried out with good color stability during 3 months of storage at room temperature.
\end{abstract}

Copyright (C) 2019 JFG-UNTAD

This open access article is distributed under a Creative Commons Attribution (CC-BY-NC-SA) 4.0 International license.

How to cite (APA 6th Style):

Asra, R., Yetti, R.D., Rusdi., Audina. S., Nessa. N, (2019). Studi Fisikokimia Betasianin Dalam Kulit Buah Naga dan Aplikasinya Sebagai Pewarna Merah Alami Sediaan Farmasi. Jurnal Farmasi Galenika :Galenika Journal of Pharmacy, 5(2), 140-146. doi:10.22487/j24428744.2019.v5.i2.13498 


\begin{abstract}
ABSTRAK
Kulit buah naga (Hylocereus lemairel (Hook.) Britton \& Rose) merupakan bahan limbah yang belum dimanfaatkan secara optimal. Kulitnya mengandung pigmen betasianin yang memiliki banyak manfaat dalam produk farmasi. Penelitian ini bertujuan untuk karakterisasi fisikokimia, mengevaluasi stabilitas dan mengaplikasikan betasianin dalam kulit buah naga sebagai pewarna alami. Proses ekstraksi dilakukan dengan menggunakan air sebagai pelarut yang disonikasi pada $50 \mathrm{kHz}$ selama 30 menit pada $25{ }^{\circ} \mathrm{C}$. Ekstrak dikering bekukan selama 48 jam. Ekstrak kering dimurnikan dengan menggunakan KLT preparatif dan dianalisis secara fisikokimia menggunakan spektrofotometer UVVis dan FTIR. Stabilitas ekstrak betasianin terhadap $\mathrm{pH}$ dan suhu diperiksa dan diaplikasikan sebagai pewarna dalam pencetakan tablet. Hasil penelitian ini menunjukkan bahwa betasianin terdeteksi pada nilai $R_{f}$ 0,6 yang sama dengan betasianin standar. Panjang gelombang maksimum betasianin diperoleh pada $534 \mathrm{~nm}$ dan spektrum IR nya menunjukkan kemiripan dengan standar betasianin dengan gugus fungsional yang sama antara 4000-600 $\mathrm{cm}^{-1}$ dengan sedikit pergeseran yang masih pada kisaran bilangan gelombang. Hasil studi stabilitas diperoleh stabil pada suhu di bawah $40{ }^{\circ} \mathrm{C}$ dan pada kisaran pH 4-6. Aplikasi betasianin sebagai pewarna alami tablet telah berhasil dilakukan dengan stabilitas warna yang baik selama 3 bulan penyimpanan pada suhu kamar.
\end{abstract}

Kata kunci: Betasianin; Kulit Buah Naga; Pewarna Alami.

\section{PENDAHULUAN}

Pewarna makanan banyak digunakan dalam proses pembuatan produk farmasi. Tujuan pewarnaan ini tidak hanya untuk meningkatkan daya tarik produk, tetapi juga untuk membantu pasien membedakan antara obat-obatan yang dikonsumsi dan membantu membedakan dosis dari obat yang sama, sehingga mengurangi kesalahan dalam penggunaan obat (S uleková et al, 2017). Berbagai zat pewarna, terutama zat pewarna sintesis memiliki dampak negatif bagi tubuh manusia karena bersifat karsinogenik, serta adanya aturan terbaru di negara Jerman, AS, India dan beberapa negara Eropa lainnya yang melarang penggunaan dari beberapa pewarna sintesis, sehingga membuat penggunaan pewarna ini semakin sedikit (Kundal et al, 2016). Hal ini menyebabkan permintaan akan pewarna alami yang berasal dari alam terus meningkat karena sifatnya yang ramah lingkungan, tidak ada efek samping, tidak beracun serta memiliki aktivitas antioksidan yang baik bagi tubuh.

Salah satu tumbuhan yang diketahui mengandung pewarna alami adalah buah naga (Hylocereus lemairel (Hook.) Britton \& Rose) atau dengan nama lain pitaya, yang merupakan famili Cactaceae (Lim, 2012). Buah naga berwarna ungu-merah ketika matang dan memiliki biji hitam disekelilingnya (Harivandaran et al, 2008). Buah naga mengandung nutrisi dan mineral seperti vitamin $B_{1}$, Vitamin $B_{2}$, Vitamin $\mathrm{B}_{3}$ dan Vitamin $\mathrm{C}$, protein lemak, karbohidrat, serat, flavonoid, tiamin, niacin, piridoksin, kobalamin, fenolik, betasianin, polifenol, karoten, fosfor, besi dan fitoalbumin (Lim, 2012). Salah satu komponen utama dalam buah naga adalah betasianin yang merupakan pigmen warna merah yang berpotensi sebagai zat warna alami (Wybraniec et al, 2001). Betasianin (6'-O-3-hydroxy-3- metilglutaril)-betanin) dengan $\mathrm{N}$-heterosiklik merupakan kelompok senyawa yang memiliki aktivitas antioksidan dan penangkal radikal bebas (Jamaludin et al, 2010). Bagian buah yang sering digunakan adalah daging buah, padahal kulit buah naga juga mengandung pigmen merah, biasanya kulit buah naga dibuang sebagai limbah makanan dan belum dimanfaatkan secara optimal. Kulit buah naga mengandung pigmen betasianin yang dapat digunakan sebagai pewarna alami. Selama ini pigmen betasianin banyak digunakan sebagai pewarna makanan (Esatbeyoglu et al, 2015), sehingga perlu dilakukan pemanfaatan pigmen betasianin yang lebih luas yaitu sebagai pewarna alami dalam sediaan farmasi. 
Secara umum, pewarna alami kurang stabil terhadap cahaya, panas, dan pada nilai $\mathrm{pH}$ tertentu jika dibandingkan dengan pewarna sintesis (Allam et al, 2011). Hal ini menjadi faktor kekurangan dalam penggunaan pewarna alami dalam sediaan farmasi. Pewarna alami dari bagian tanaman yang berbeda dapat diekstraksi melalui berbagai metode seperti menggunakan pelarut air, pelarut organik dan ekstraksi yang dibantu oleh enzim (Ghoreishian et al, 2013). Namun dari metode-metode yang telah dilakukan, belum diperoleh metode yang tepat dan baik dalam mengekstraksi zat warna merah dalam buah naga.

Penelitian ini bertujuan untuk mengekstraksi zat warna merah betasianin dari kulit buah naga menggunakan metode ekstraksi yang dioptimasi yaitu menggunakan teknik ekstraksi ultrasonik untuk mendapatkan kualitas zat warna betasianin yang bermutu dan di karakterisasi secara fisikokimia. Kemudian, zat merah betasianin yang dihasilkan dari kulit buah naga diuji stabilitasnya terhadap suhu dan $\mathrm{pH}$. Kemudian zat merah betasianin tersebut diaplikasikan sebagai coloring agent pada formulasi sediaan farmasi, sehingga diharapkan hasil penelitian ini dapat menjadi alternatif penggunaan pewarna alami untuk sediaan farmasi, meningkatkan pemanfaatan limbah kulit buah naga dan dapat mengurangi masalah pencemaran lingkungan karena pewarna alami lebih ramah lingkungan dan aman.

\section{METODE PENELITIAN}

\section{Alat dan Bahan}

Bahan-bahan yang digunakan pada penelitian ini adalah kulit buah naga (Hylocereus lemairel (Hook.) Britton \& Rose), air suling $\left(\mathrm{H}_{2} \mathrm{O}\right)$ (PT Brataco), metanol p.a $\left(\mathrm{CH}_{3} \mathrm{OH}\right)$ (Merck), natrium hidroksida $(\mathrm{NaOH})$ (PT Brataco), asam klorida (HCl) (Merck), betasianin standar (Sigma Aldrich ${ }^{\circledR}$ ), amilum (PT Bratachem), talk (PT Bratachem), amprotab (PT Bratachem), parasetamol (PT Bratachem), dan Avicel ${ }^{\circledR} \mathrm{PH}$.

Alat-alat yang digunakan dalam penelitian ini adalah Spektrofotometer UV-Vis (Shimadzu UV-1800), Fourier Tranform Infrared (FTIR) (PerkinElmer), sonicator water bath (Elmasonic), Freeze Dryer (Alpha 1-2 LDplus ${ }^{\circledR}$ ), sentrifus (Biofuge Primo R), kertas saring Whatman No. 1, plat KLT sillika gel 60 $\mathrm{F}_{254}$ (Merck), dan lampu sinar $\mathrm{UV}_{254}$ (Camag).

\section{Pengambilan Sampel}

Sampel yang digunakan pada penelitian ini adalah buah naga merah (Hylocereus lemairel (Hook.) Britton \& Rose) segar yang diambil sebanyak $5 \mathrm{~kg}$ yang diperoleh dari Kamang, Kabupaten Agam, Sumatera Barat.

\section{Determinasi Sampel}

Determinasi dilakukan di Herbarium FMIPA Universitas Andalas (ANDA) Padang.

\section{Penyiapan Sampel}

Buah naga dikupas dan dibersihkan untuk dipisahkan daging buah dengan kulitnya. Kemudian kulit buah naga dicuci bersih dan diblender hingga halus.

\section{Proses Ekstraksi Betasianin}

Proses ekstraksi betasianin menggunakan teknik ekstraksi ultrasonik (Ultrasonic Assisted Extraction). Sebanyak 1000 g kulit buah naga dihomogenkan dengan $500 \mathrm{ml}$ air suling 2:1 (b/v). Campuran kemudian ditempatkan dalam ultrasonic bath dan disonikasi pada $50 \mathrm{kHz}$ selama 30 menit pada suhu $25{ }^{\circ} \mathrm{C}$. Ampasnya dipisahkan dari ekstrak menggunakan corong Buchner funnel melalui kertas saring Whatman No. 1 sehingga diperoleh larutan berwarna. Residu diekstraksi kembali dengan aquadest sebanyak 3 kali. Ekstrak kemudian disentrifugasi pada $6000 \mathrm{rpm}$ selama 15 menit pada suhu kamar dan supernatannya disimpan pada suhu 4 ${ }^{\circ} \mathrm{C}$ untuk menjaga kestabilan warna ekstrak sebelum digunakan.

\section{Rendemen Ekstrak}

Ekstrak yang diperoleh di freeze drying, kemudian ekstrak kering ditimbang dan rendemennya dihitung per $1 \mathrm{~g}$ sampel.

Rendemen ekstrak dihitung dengan rumus:

$$
\text { \% Rendemen: } \frac{\text { berat ekstrak }}{\text { berat sampel }} \times 100 \%
$$

\section{Uji Kromatografi Lapis Tipis (KLT)}

Ekstrak dipisahkan menggunakan plat silica $\mathrm{F}_{254}$ 10x10 cm (KLT preparatif) dengan campuran metanol: asam asetat (6:4 (v/v)). 1gram ekstrak kulit dan betasianin standar dilarutkan dengan fase gerak sebanyak $10 \mathrm{~mL}$, kemudian ditotolkan pada plat dan 
dielusi. Nilai $\mathrm{R}_{\mathrm{f}}$ dari noda dihitung dan diperiksa di bawah sinar UV pada $254 \mathrm{~nm}$ dan $366 \mathrm{~nm}$ dan dibandingkan dengan standar.

\section{Penetapan Panjang gelombang Maksimum Betasianin}

Isolat KLT preparatif diperoleh dengan cara mengerok fasa diam ditempat noda sampel pada plat, lalu dilarutkan dengan metanol sebanyak $10 \mathrm{~mL}$ dan disentrifugasi. Supernatannya diambil dan dimasukkan dalam kuvet kemudian dianalisis dengan spektrofotometer UV-Vis, sedangkan untuk betasianin standar dibuat konsentrasi $1000 \mu \mathrm{g} / \mathrm{mL}$. Pengukuran panjang gelombang maksimum betasianin sampel dan standar diukur pada 400-700 nm menggunakan spektrometer UV-Vis.

\section{Analisis Gugus Fungsi Betasianin}

Analisis gugus fungsi betasianin sampel dan standar diukur menggunakan Spektrometer FTIR. Spektrum isolat dan standar diukur pada bilangan gelombang 600-4000 $\mathrm{cm}^{-1}$. Analisis ini akan memperlihatkan spektrum yang menggambarkan gugus fungsional dari senyawa betasianin.

\section{Uji Stabilitas Betasianin Terhadap Suhu Dan pH}

Uji stabilitas dari betasianin sampel dilakukan terhadap suhu $\left(25^{\circ} \mathrm{C}, 40^{\circ} \mathrm{C}, 60^{\circ} \mathrm{C}, 80^{\circ} \mathrm{C}\right.$ dan $\left.100^{\circ} \mathrm{C}\right)$ dan $\mathrm{pH}(2 ; 3 ; 4 ; 5 ; 6 ; 7 ; 8 ; 9 ; 10 ; 11 ; 12)$ dengan penambahan $\mathrm{HCl} 1 \%$ dan $\mathrm{NaOH} 1 \%$ dalam waktu 30 menit, kemudian absorban diukur menggunakan spektrofotometer UV-Vis pada panjang gelombang maksimum betasianin kulit buah naga.

\section{Aplikasi Zat Warna Merah Dalam Formulasi Tablet Parasetamol}

Ekstrak diaplikasikan dalam pembuatan tablet parasetamol menggunakan metode kempa langsung dengan formula: Paracetamol $250 \mathrm{mg}$, amilum $10 \%$, Talkum $5 \%$, betasianin serbuk qs, Avicel®PH 102 ditambahkan sampai bobot total $300 \mathrm{mg}$, dibuat untuk 20 tablet. Tablet yang dihasilkan dievaluasi stabilitas warna tablet pada rentang bulan ke 0, 1, 2 dan 3 penyimpanan.

\section{HASIL DAN PEMBAHASAN}

Kulit buah naga mengandung pigmen yang disebut betasianin. Betasianin adalah pigmen merah yang memiliki banyak manfaat, salah satunya dalam sediaan farmasi sebagai pewarna alami dalam pencetakan tablet. Betasianin diekstraksi menggunakan metode Ultrasonic Assisted Extraction (UAE). Metode ini menggunakan ultrasonik yang dapat menyebabkan efek kavitasi untuk menghancurkan dinding sel sehingga betasianin dilepaskan dengan mudah sehingga memaksimalkan hasil ekstraksi (Kuldikole et al, 2002). Metode pengeringan yang digunakan adalah menggunakan metode freeze drying untuk menghilangkan pelarut air. Metode ini bertujuan untuk menjaga kualitas sampel karena betasianin tidak stabil terhadap pemanasan. Sampel dibekukan terlebih dahulu untuk membentuk fase padat, kemudian dikeringkan menggunakan freeze dryer. proses sublimasi terjadi membentuk ekstrak kering betasianin. Betasianin yang diperoleh dari metode ini adalah 17,6 \% b/b.

Kondisi optimum untuk analisis betasianin menggunakan KLT dilakukan secara eksperimental dengan mempertimbangkan efek dari beberapa faktor seperti konsentrasi larutan, rasio pelarut dalam eluen dan jenis pelat KLT. Fase gerak yang digunakan adalah metanol/asam asetat (6: 4) yang memberikan resolusi dan kromatogram yang baik dengan nilai $R_{f}$ 0,6 yang sama dengan betasianin standar (Sigma Aldrich $^{\circledR}$ ). Betasianin dimurnikan dan isolatnya dianalisis menggunakan Spektrofotometer UV-Vis Shimadzu UV-1800 ${ }^{\circledR}$ dan spektrometer FTIR PerkinElmer ${ }^{\circledR}$. Hasil penelitian menunjukkan bahwa sampel dan standar memiliki $\lambda_{\max }$ pada $534 \mathrm{~nm}$. Betasianin menyerap cahaya dengan kuat pada panjang gelombang 532-538 nm (Harbone, 1987).

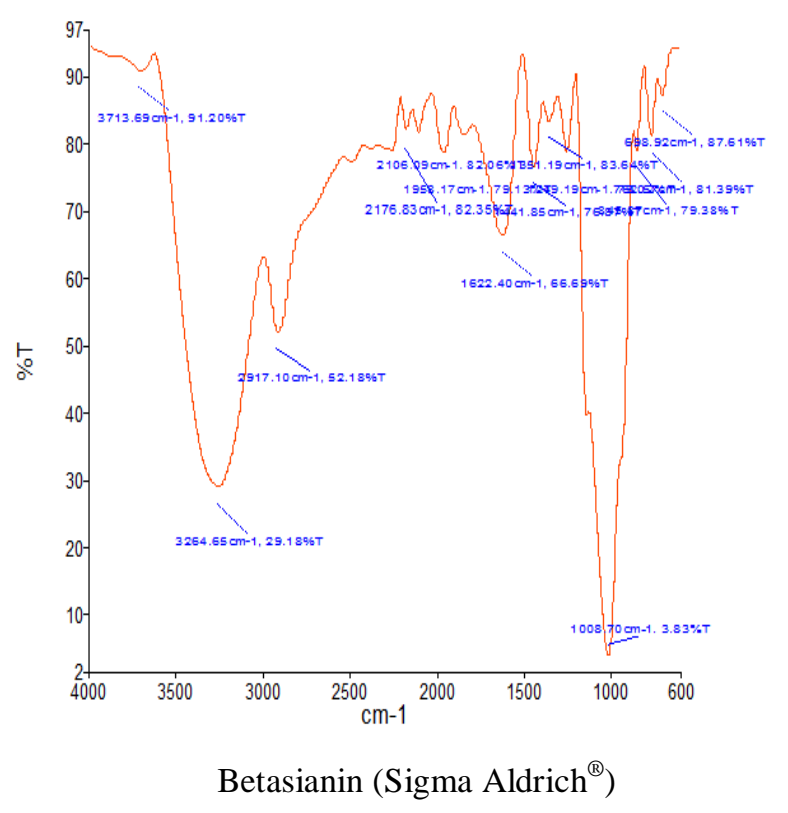




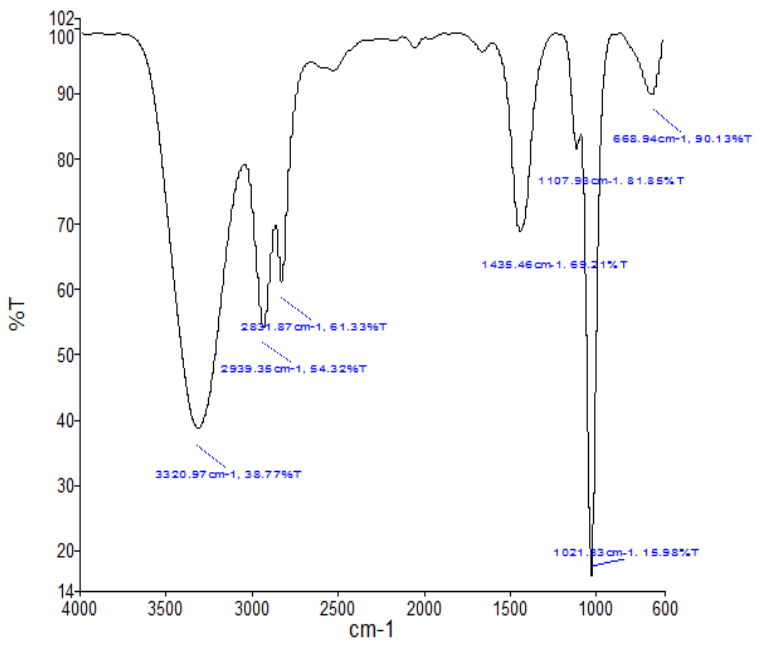

Betasianin Kulit Buah Naga

Gambar 1. Spektrum FTIR betasianin dalam metanol pada bilangan gelombang $600-4000 \mathrm{~cm}^{-1}$

Spektrum betasianin diukur pada bilangan gelombang 600-4000 $\mathrm{cm}^{-1}$. Seperti yang ditunjukkan pada Gambar. 1, spektrum FTIR betasianin sampel menunjukkan kesamaan dengan betasianin standar, meskipun ada sedikit perbedaan namun masih dalam rentang bilangan gelombang. Bilangan gelombang $3714 \mathrm{~cm}^{-1}$ dan $3321 \mathrm{~cm}^{-1}$ dari betasianin standar dan sampel menunjukkan spektrum ikatan $\mathrm{O}-\mathrm{H}$ dan $\mathrm{N}-\mathrm{H}$. Ikatan O-H dan N-H berada pada bilangan gelombang antara $3800-3200 \mathrm{~cm}^{-1}$ (Field et al, 2008). Bilangan gelombang $2917 \mathrm{~cm}^{-1}$ dan $2831 \mathrm{~cm}^{-1}$ dari betasianin standar dan sampel adalah spektrum ikatan $\mathrm{C}-\mathrm{H}$ dan $\mathrm{CH}_{2}$. Bilangan gelombang $699 \mathrm{~cm}^{-1}$ dan 668 $\mathrm{cm}^{-1}$ dari betasianin standar dan sampel adalah spektrum ikatan $\mathrm{C}=\mathrm{CH}$.

Stabilitas pigmen betasianin dipengaruhi oleh suhu dan $\mathrm{pH}$. Hal ini dapat dilihat pada perubahan warna larutan dari merah menjadi kuning dan pengurangan absorbansi betasianin. Hasil penelitian menunjukkan bahwa betasianin stabil pada suhu di bawah $40{ }^{\circ} \mathrm{C}$ dan pH 4-6 seperti yang ditunjukkan pada Gambar. 2. Pada suhu tinggi dan $\mathrm{pH}$ kritis, Terjadi reaksi hidrolisis pada ikatan $\mathrm{N}=\mathrm{C}$ yang menyebabkan betasianin berubah menjadi asam betalamat (kuning) dan siklo-Dopa 5-O-glikosida. Sedangkan pada $\mathrm{pH}$ yang lebih rendah, deglikolisasi terjadi pada betasianin menjadi betanidin. Ikatan antara betasianin dan glikosida adalah ikatan asetal yang mudah putus oleh asam kuat seperti asam klorida (Herbach, 2006).
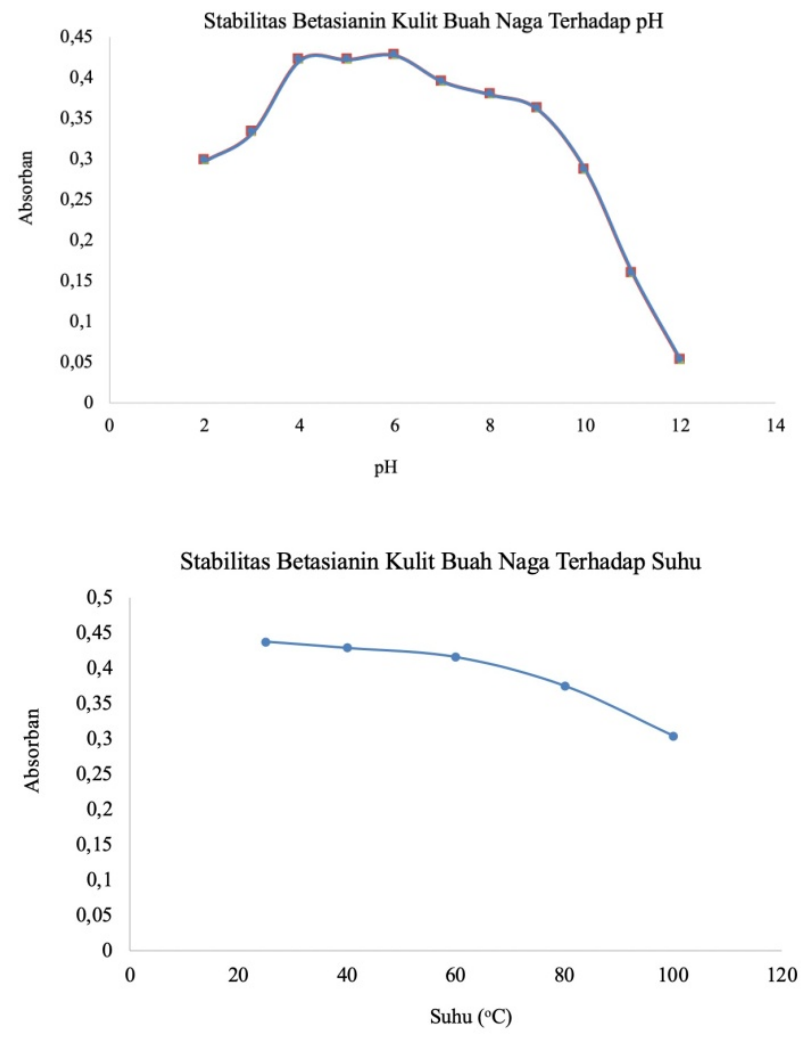

Gambar 2. Grafik Stabilitas Betasianin Kulit Buah Naga Terhadap Suhu dan $\mathrm{pH}$

Aplikasi betasianin sebagai pewarna alami dalam percetakan tablet telah berhasil dilakukan. Warna dari tablet yang dihasilkan berwarna merah muda dan tablet disimpan dan dievaluasi selama 3 bulan. Hasil penelitian dapat dilihat pada Gambar 3. Selama 3 bulan penyimpanan, tidak terjadi perubahan warna tablet yang signifikan. Dapat disimpulkan bahwa betasianin kulit buah naga dapat digunakan sebagai colouring agent dalam sediaan farmasi. 


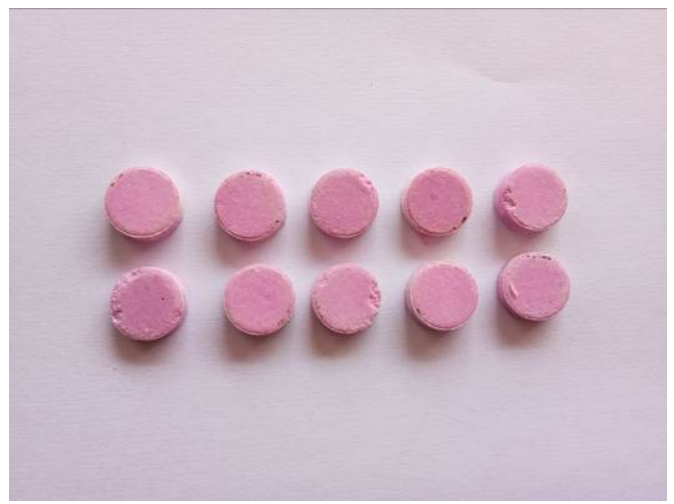

0 Bulan

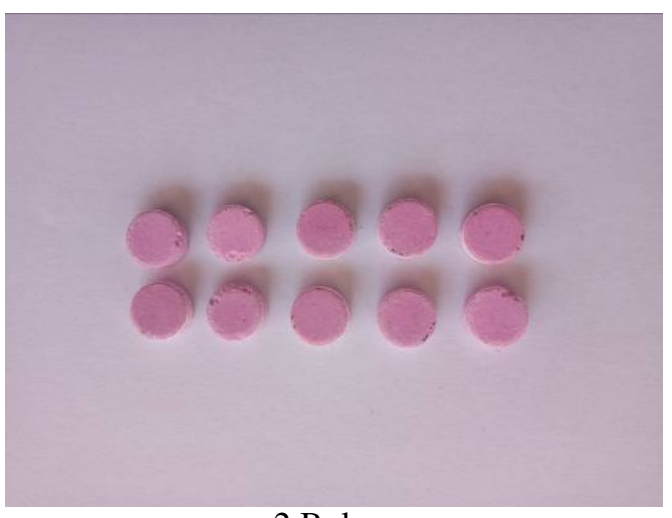

2 Bulan

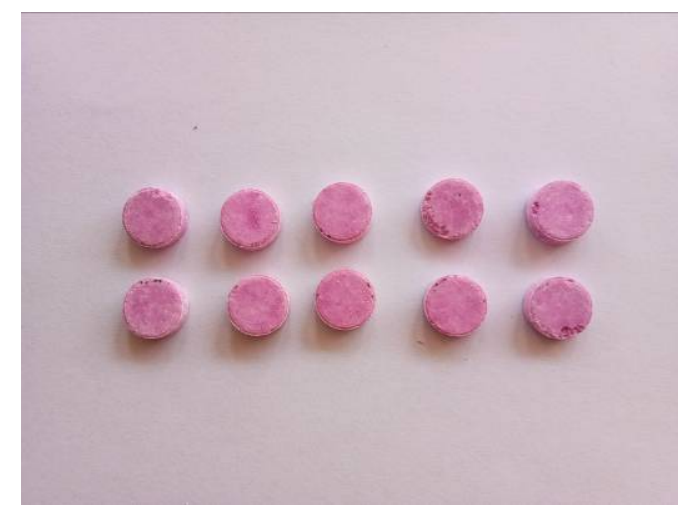

1 Bulan

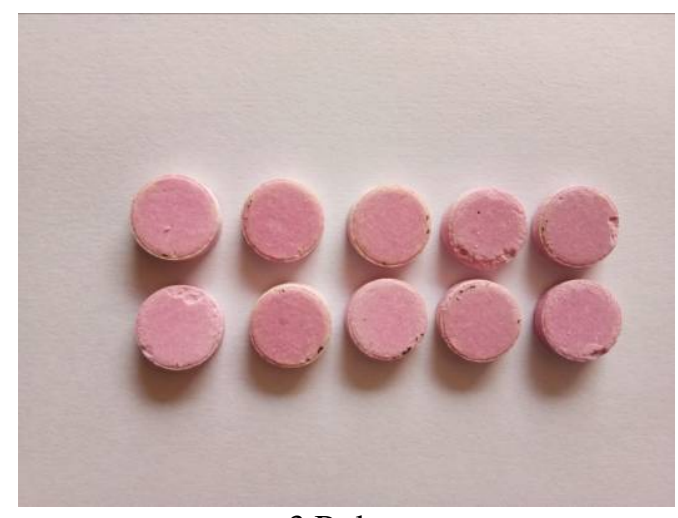

3 Bulan

Gambar 3. Tablet yang Dihasilkan Menggunakan Pewarna Betasianin Kulit Buah Naga

\section{KESIMPULAN}

Betasianin kulit buah naga telah berhasil diisolasi dan dikarakterisasi secara fisikokimia. Metode ekstraksi yang digunakan sederhana, fleksibel, murah dan ramah lingkungan. Hasil penelitian ini menunjukkan kemiripan antara betasianin sampel dan betasianin standar Sigma Aldrich ${ }^{\circledR}$ dan betasianin kulit buah naga dapat digunakan sebagai alternatif colouring agent dalam sediaan Farmasi. Stabilitas warna dari tablet yang dihasilkan dipengaruhi oleh penyimpanan. Warna akan bertahan lebih lama jika disimpan pada kondisi kestabilan betasianin yaitu pada suhu kurang dari $40^{\circ} \mathrm{C}$ dan pada rentang $\mathrm{pH}$ 46.

\section{UCAPAN TERIMAKASIH}

Peneliti mengucapkan terimakasih kepada Direktorat Riset dan Pengabdian Masyarakat, Direktorat
Jenderal Penguatan Riset dan Pengembangan, Kementerian Riset, Teknologi, dan Pendidikan Tinggi, atas bantuan dana penelitian dosen pemula, sesuai Kontrak Penelitian Tahun Anggaran 2019.

\section{DAFTAR PUSTAKA}

Allam, K.V., Kumar, G. (2011). Colorants - the cosmetics for the pharmaceutical dosage forms. Int. J. Pharm. Pharm. Sci., 3 (1), 13-21.

Esatbeyoglu, T., Wagner, A.E., Rimbach, G. (2015). Betanin: a food colorant with biological activity. Mol Nutr Food Res, 59(1), 36-47.

Field, L.D., Strenhel, S., Kalman, J. R. (2008). Organic structures from spectra $\left(4^{\text {th }} \mathrm{ed}\right)$. England: John wiley and sons LTD. 
Ghoreishian, S.M., Maleknia, L., Mirzapour, H., Norouzi, M. (2013). Antimicrobial properties and color fastness of silk fabric dyed with turmeric extract. Fibres and polymers, 14 (2), 201-207.

Harborne, J.B. (1987). Phytochemical methods. (2nd Edition). Bandung: ITB.

Harivandaran, K.V., Rebecca, O.P., Chandran, S. (2008). Study of Optimal Temperature, $\mathrm{pH}$ and Stability of Dragon Fruit (Hylocereus polyrhizus) peel for use as potential Natural Colorant. Pakistan Journal of Biological Sciences, 11(18), 2259-2263.

Herbach, K.M., Stinzing, F.C., Carle, R. (2006). Betalain stability and degradation structural and chromatic aspect. Journal of Food Science, $71,41-50$.

Jamaludin, N.A., Phebe, D., Hamid, A.A. (2010). Physico-chemical and structural changes of red-fleshed dragon fruit (Hylocereus polyrhizus) during fruit development. J Sci Food Agric, 91(1), 278-285.

Kuldikole, J. (2002). Effect of ultrasound, temperature and pressure treatments on enzym activity and quality indicators of fruit and vegetables juices. Berlin: Dissetation der Techischen University Berlin.

Kundal, J., Singh, S.V., Purohit, M.C. (2016). Extraction of natural dye from Ficus cunia and dyeing of polyester cotton and wool fabric using different mordants with evaluation of colour fastness properties. Natural Product Chemistry and Research, 4(3), 3-6.

Lim, T. K. (2012). Hylocereus polyrhizus. In L. T. K., Edible Medicinal and Non-Medicinal Plants (hal. 643-649).

Suleková, M., Smrcová, M., Hudák, A., Hezelová, M., Fedorová, M. (2017). Organic Colouring Agents in The Pharmaceutical Industry. Folia Veterinaria, 61(3), 32-46.

Wybraniec, S.I., Platzner, S. G. (2001). Betacyanins from vine cactus Hylocereus polyrhizus. Phytochemistry, 58(8), 1209-1212. 